Marina Kolundžić ${ }^{1}$, Jelena Radović ${ }^{1}$, Ana Tačić ${ }^{2}$, Vesna Nikolić ${ }^{2}$, Tatjana Kundaković ${ }^{1 *}$

1 University of Belgrade, Faculty of Pharmacy, Department of Pharmacognosy, Belgrade, Serbia, ${ }^{2}$ University of Niš, Faculty of Technology, Department of Organic and Technological Sciences, Leskovac, Serbia
Scientific paper

ISSN 0351-9465, E-ISSN 2466-2585

UDC:635.8:635.81.095.337

doi: $10.5937 /$ ZasMat $1801045 \mathrm{~K}$

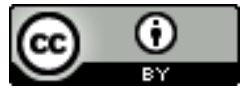

Zastita Materijala $59(1)$

$45-50$ (2018)

\title{
Elemental composition and nutritional value of three edible mushrooms from Serbia
}

\begin{abstract}
Nutrition value, as well as macro- and microconstituents of three edible mushrooms (Pleurotus ostreatus, Lentinula edodes, Macrolepiota procera) collected in Serbia were tested. It has been determined that all three mushroom samples were low in energy, fat and carbohydrates, but rich in $\beta$-glucans content. The most abundant elements in these three mushrooms were essential marcroelements $\mathrm{Ca}, \mathrm{K}$ and $\mathrm{P}$, but also there is a significant amount of $\mathrm{Li}$, Se and $\mathrm{Zn}$. On the other hand, toxic elements, such as $\mathrm{Pb}$, As and $\mathrm{Cd}$ were also detected in level higher than allowed.
\end{abstract}

Keywords: Pleurotus ostreatus, Lentinula edodes, Macrolepiota procera, nutrition value, elemental analysis.

\section{INTRODUCTION}

Mushrooms have an important role as decomposers in nature, assimilating elements and converting them into simpler substances [1]. Also, fresh and preserved mushrooms are consumed in many countries as a delicacy, particularly for their specific aroma and texture [2]. Knowledge of the composition and nutritional value of culinary mushrooms, particularly of wild-growing ones, was limited until the last decade [2]. Apart from flavor and taste, the fruiting bodies of mushrooms are considered to be the sources of organic nutrients such as digestible proteins, carbohydrates, fibre and certain vitamins, as well as minerals and antioxidants [3]. In fungal cell wall there is a complex network of fibers ( $\beta$-glucans, chitin, mannoproteins, galactomannan, etc.) that provide structure, protection and rigidity to cell wall. Some of these fibers also possess therapeutic properties. $\beta$-glucans are the most important constituents, as they show antitumor, immunomodulatory, antimicrobial, antinociceptive, antiinflamatory, antioxidant, hypoglycemic activity [1].

\footnotetext{
${ }^{*}$ Corresponding author: Tatjana Kundaković e-mail: ktatjana@pharmacy.bg.ac.rs

Paper received: 30. 08. 2017.

Paper accepted: 18. 10. 2017.

Paper is available on the website: www.idk.org.rs/journal
}

In this study, we investigated the content of macro- and microconstituents, as well as nutritional value and $\beta$-glucan content of three common edible mushrooms: Pleurotus ostreatus (Jack.:Fr) Kummer (1871), Lentinula edodes (Berk.) Pegler (1976), Macrolepiota procera (Scop.:Fr) Singer (1948).

\section{EXPERIMENTAL PART}

\subsection{Mushroom material}

Fruiting bodies of three edible mushrooms, $P$. ostreatus, $L$. edodes and $M$. procera were purchased on local market in Belgrade, Serbia in July 2014. Mushrooms were dried at room temperature and pulverized in a laboratory mill. The voucher specimens were deposited at the Faculty of Pharmacy, Department of Pharmacognosy (Nos 26, 27 and 28).

\subsection{Determination of nutritional value}

The sample of dried material was analyzed for the percentage of moisture, proteins, fats, carbohydrates and ash. All values were calculated on a dry weight (d.w.) of mushroom. Nutritional value was determined by using the procedures described by the Association of Official Analytical Chemists (AOAC 1990) [4]. The moisture and ash contents were estimated using gravimetric methods after drying at $105^{\circ} \mathrm{C}$, and incineration at $550^{\circ} \mathrm{C}$, respectively. The crude protein content by the Kjeldahl method and the nitrogen factor used for 
protein calculation was 6.25 , while the crude fats were determined using the extraction procedure on Soxhlet apparatus, using petroleum ether as a solvent, after the treatment with $\mathrm{HCl}$.

Total carbohydrates were calculated as the residual difference after subtracting protein, ash, moisture, total fibre and crude fat content. Total energy was determined by the calculation of energy values of carbohydrate, fat, protein and fibre. Energy, kcal $=9$ (crude fat content, g) +4 (protein content, $\mathrm{g}+$ carbohydrate content, $\mathrm{g}$ ) +2 (fibre content, g).

\subsection{Determination of $\beta$-glucans}

Enzymatic assay kit K-YBGL (Megazyme International Ireland) was used in order to determine content of $\beta$-glucans in both dried and cooked samples. The assay performed according to the instruction manual of the kit producer. In short, content of $\beta$-glucans was calculated indirectly from the difference in total glucans content and $\alpha$-glucans content. After solubilisation in concentrated $(37 \% ; 10 \mathrm{~N}) \mathrm{HCl}$, total glucans (1,3:1,6- $\beta$-D-glucan, $1,3-\beta$-D-glucans and $\alpha$ glucans) were extensively hydrolyzed by $1.3 \mathrm{~N} \mathrm{HCl}$ at $100^{\circ} \mathrm{C}$ for $2 \mathrm{~h}$. In addition, mixture was incubated with highly purified enzymes i.e. exo-1,3- $\beta$ glucanase and $\beta$-glucosidase. The measurement of $\alpha$-glucans content was performed after hydrolysis with mixture of amyloglucosidase and invertase. All glucans split into their glucose monomers, and measured spectrophotometrically $(510 \mathrm{~nm})$.

\subsection{Determination of macro- and microelements}

Preparation of the sample for determining heavy metal concentration carried out by wet digestion using nitric acid. The weighed mass of dry sample $(0.01 \mathrm{~g})$ topped with $1 \mathrm{ml}$ of concentrated nitric acid and allowed to stand for 24 hours. Thereafter, the mixture heated at the acid boiling temperature until brown vapors of nitrogen oxide stopped forming. After digestion, the sample was filtered and the filtrate transferred to a volumetric flask and filled with distilled water up to $10 \mathrm{ml}$.

All measurements were done in triplicate on ICP-OES (Inductively Coupled Plasma - Optical Emission Spectrometry, ARCOS FHE12, SPECTRO, Germany) according to the instruction for the quantitative analysis given by the manufacturer. Argon 5.0 (purity 99.999\%) was used as a carrier gas. Except the sample for the analysis, the solution for the calibration curve construction were prepared using Multistandard IV - multi-element standard solution, which contained $\mathrm{Ag}, \mathrm{Al}, \mathrm{B}, \mathrm{Ba}, \mathrm{Bi}, \mathrm{Ca}, \mathrm{Cd}, \mathrm{Co}, \mathrm{Cr}, \mathrm{Cu}, \mathrm{Fe}, \mathrm{Ga}, \mathrm{In}, \mathrm{K}$, $\mathrm{Li}, \mathrm{Mg}, \mathrm{Mn}, \mathrm{Na}, \mathrm{Ni}, \mathrm{Pb}, \mathrm{Sr}, \mathrm{Se}, \mathrm{TI}, \mathrm{V}$ and $\mathrm{Zn}$, and also specific standard solution of $\mathrm{Si}, \mathrm{As}, \mathrm{P}, \mathrm{Mo}$ and $\mathrm{Sb}$ in concentration of $1000 \mathrm{ppm}$.

\section{RESULTS AND DISCUSSION}

\subsection{Nutritional value and $\beta$-glucans content}

According to recent data, normal medians of crude protein, lipid and ash content of numerous wild-growing mushroom species were 250, 30 and $80 \mathrm{~g} / \mathrm{kg}$ d.w., respectively [2]. Table 1 presents the nutritional values of mushrooms tested in this study. The content of proteins was lower in samples of $P$. ostreatus and $L$. edodes, while fat content of $L$. edodes and $M$. procera was higher than samples from literature data. The protein content was much higher in $M$. procera than the average content in mushrooms $(337.7 \mathrm{~g} / \mathrm{kg})$.

\section{Table 1. Nutritional value of dried mushrooms}

Tabela 1.Nutritivna vrednost osušenih pečuraka

\begin{tabular}{|l|c|c|c|}
\hline \multicolumn{1}{|c|}{ Parameter } & $\begin{array}{c}\text { Pleurotus } \\
\text { ostreatus }\end{array}$ & $\begin{array}{c}\text { Lentinula } \\
\text { edodes }\end{array}$ & $\begin{array}{c}\text { Macrolepiota } \\
\text { procera }\end{array}$ \\
\hline $\begin{array}{l}\text { Moisture } \\
(\mathrm{g} / \mathrm{kg})\end{array}$ & 80.9 & 108.6 & 62.2 \\
\hline Ash $(\mathrm{g} / \mathrm{kg})$ & 81.6 & 32.1 & 74.0 \\
\hline Fat $(\mathrm{g} / \mathrm{kg})$ & 39.4 & 70.4 & 50.6 \\
\hline $\begin{array}{l}\text { Proteins as } \\
\text { Nx6.25 }(\mathrm{g} / \mathrm{kg})\end{array}$ & 22.6 & 23.8 & 337.7 \\
\hline $\begin{array}{l}\text { Carbohydrates } \\
\text { (g/kg) }\end{array}$ & 304.9 & 251.8 & 77.7 \\
\hline $\begin{array}{l}\text { Energy } \\
(\mathrm{kcal} / \mathrm{kg})\end{array}$ & 1664.6 & 1736.0 & 2912.6 \\
\hline Energy $(\mathrm{kJ} / \mathrm{kg})$ & 7025.3 & 7290.0 & 12174.7 \\
\hline
\end{tabular}

$\beta$-Glucans are polysaccharides present in fungal cell wall. These biomolecules exhibit important medicinal effects [1]. Lentinan, $\beta$-glucan isolated from L.edodes, and pleuran, isolated from $P$.ostreatus, showed positive effect on immune system [5][6]. In recent study, the content of $\beta$ glucans in 39 commercially cultivated and wild mushrooms was analysed. $\beta$-glucan content in $P$. ostreatus (whole mushroom), L. edodes (cap and stalk), as well as Macrolepiota fuliginosa (cap and stalk) were 24,231 g/100g d.w.; 19,779 g/100g d.w.; 25,309 g/100g d.w., 13,952 g/100g d.w. and $13,118 \mathrm{~g} / 100 \mathrm{~g}$ d.w., respectively [7]. Culinary treatment have influence on proximate composition of mushrooms [8]. Results of our study indicate that thermal treatment (boiling at $100^{\circ} \mathrm{C}$ ) can drastically decrease the content of $\beta$-glucans in mushrooms, approximately $90 \%$. (Table 2 ). 
Table 2: The content of $\alpha$-, $\beta$ - and total glucan in dry and cooked mushroom (g/100g)

Tabela 2: Sadržaj $\alpha$-, $\beta$ - i ukupnih glukana u osušenim i kuvanim pečurkama $(g / 100 g)$

\begin{tabular}{|c|c|c|c|}
\hline Different prepared samples & a-glucan & $\beta$-glucan & Total glucan \\
\hline \multicolumn{4}{|c|}{ Pleurotus ostreatus } \\
\hline Dried & $3.27 \pm 0.01$ & $47.14 \pm 0.61$ & $50.42 \pm 0.60$ \\
\hline Cooked & $0.32 \pm 0.01$ & $8.65 \pm 0.14$ & $8.97 \pm 0.15$ \\
\hline \multicolumn{4}{|c|}{ Lentinula edodes } \\
\hline Dried & $1.42 \pm 0.00$ & $33.98 \pm 0.31$ & $35.40 \pm 0.31$ \\
\hline Cooked & $0.22 \pm 0.01$ & $3.99 \pm 0.08$ & $4.21 \pm 0.09$ \\
\hline \multicolumn{4}{|r|}{ Macrolepiota procera } \\
\hline Dried & $1.30 \pm 0.07$ & $11.20 \pm 0.57$ & $12.50 \pm 0.63$ \\
\hline Cooked & $0.16 \pm 0.01$ & $1.42 \pm 0.06$ & $1.58 \pm 0.06$ \\
\hline
\end{tabular}

\subsection{Micro- and macroelements}

Mushrooms are very good source of minerals [9], but also could be enriched with selenium and lithium $[9,10,11]$. The most common macroelements in mushrooms are calcium, potassium, sodium and phosphorus, as well as magnesium, copper and zinc [3]. These metals are among the vital ions to body liquids and tissues and are cofactors of numerous enzymes [9]. The most abundant mineral in all three mushroom samples was calcium, followed by potassium. On the other hand, the concentration of sodium in all three samples is very low. For overall therapy of hypertension $\mathrm{Na} / \mathrm{K}$ ratio is very important.

Table 3. Micro- and macroelements in mushrooms samples $(\mu \mathrm{g} / \mathrm{g})$.

Tabela 3. Mikro- i makroelementi u uzorcima pečuraka $(\mu \mathrm{g} / \mathrm{g})$.

\begin{tabular}{|c|c|c|c|}
\hline Element & $\begin{array}{c}\text { Pleurotus } \\
\text { ostreatus }\end{array}$ & $\begin{array}{c}\text { Lentinula } \\
\text { edodes }\end{array}$ & $\begin{array}{c}\text { Macrolepiot } \\
\text { a procera }\end{array}$ \\
\hline $\mathrm{Ag}$ & 0 & 0 & 0 \\
\hline $\mathrm{Al}$ & 273 & 141 & 239 \\
\hline $\mathrm{As}$ & 20 & 10 & 16 \\
\hline $\mathrm{B}$ & 96 & 0 & 26 \\
\hline $\mathrm{Ba}$ & 118 & 62 & 94 \\
\hline $\mathrm{Bi}$ & 25 & 24 & 25 \\
\hline $\mathrm{Ca}$ & 78031 & 46678 & 99126 \\
\hline $\mathrm{Cd}$ & 0 & 2 & 0 \\
\hline $\mathrm{Co}$ & 0 & 0 & 0 \\
\hline $\mathrm{Cr}$ & 0 & 0 & 0 \\
\hline $\mathrm{Cu}$ & 147 & 63 & 109 \\
\hline $\mathrm{Fe}$ & 88 & 28 & 69 \\
\hline $\mathrm{Ga}$ & 0 & 0 & 0 \\
\hline $\mathrm{Ge}$ & 72 & 69 & 71 \\
\hline $\mathrm{In}$ & 23 & 22 & 21 \\
\hline & & & \\
\hline
\end{tabular}

\begin{tabular}{|c|c|c|c|}
\hline $\mathrm{K}$ & 26942 & 7972 & 12169 \\
\hline $\mathrm{Li}$ & 5 & 4 & 5 \\
\hline $\mathrm{Mg}$ & 1658 & 959 & 1353 \\
\hline $\mathrm{Mn}$ & 0 & 0 & 0 \\
\hline $\mathrm{Mo}$ & 31 & 27 & 26 \\
\hline $\mathrm{Na}$ & 2609 & 1936 & 2316 \\
\hline $\mathrm{Ni}$ & 0 & 0 & 0 \\
\hline $\mathrm{P}$ & 21634 & 13251 & 20137 \\
\hline $\mathrm{Pb}$ & 0 & 0 & 2 \\
\hline $\mathrm{Pt}$ & 470 & 443 & 446 \\
\hline $\mathrm{Sb}$ & 0 & 0 & 0 \\
\hline $\mathrm{Si}$ & 1165 & 871 & 1078 \\
\hline $\mathrm{Sr}$ & 10 & 5 & 15 \\
\hline $\mathrm{TI}$ & 0 & 0 & 0 \\
\hline $\mathrm{Zn}$ & 110 & 125 & 94 \\
\hline $\mathrm{Se}$ & 69 & 67 & 67 \\
\hline
\end{tabular}

In patients with hypertension, the lower sodium intake, recommended by American Heart Association, should be less than $2.3 \mathrm{~g}$, or maximal $6 \mathrm{~g}$ of sodium chloride. $\mathrm{Na} / \mathrm{K}$ ratio for our samples was also very low 0.190 for $M$. procera, 0.24 for $L$. edodes and 0.09 for $P$. ostreatus. Concerning the effects on blood pressure, the low concentration of sodium and the presence of a great amount of potassium supports the utilization of mushrooms within an antihypertensive diet.

The order of other elements in our samples was: $\mathrm{Ca}>\mathrm{K}>\mathrm{P}>\mathrm{Na}>\mathrm{Mg}>\mathrm{Si}>\mathrm{Pt}>\mathrm{Al}>\mathrm{Zn}>\mathrm{Mn}>\mathrm{Fe}>\mathrm{Ge}>$ $>\mathrm{Se}>\mathrm{Ba}>\mathrm{Cu}>\mathrm{Mo}>\mathrm{Bi}>\mathrm{In}>\mathrm{As}, \mathrm{B}>\mathrm{Sr}>\mathrm{Li}>\mathrm{Pb}$. Ag, Cd, $\mathrm{Co}, \mathrm{Cr}, \mathrm{Ga}, \mathrm{Ni}$, Sb and TI had not been detected. In a review paper by Falandysz and Borovička (2013) the content of the most frequent micro- and macroelements occurring in edible mushrooms was presented [9]. We can conclude that the 
concentrations of the majority of elements in our samples ( $\mathrm{Ca}, \mathrm{K}, \mathrm{P}, \mathrm{Na}, \mathrm{Mg}, \mathrm{Cu}$, Se, $\mathrm{Zn}$, etc.) are within the range of concentrations measured by other researchers so far.

M. procera and $P$. ostreatus had the highest amount of Li $(5 \mu \mathrm{g} / \mathrm{g})$. According to Vetter (2005), the highest $\mathrm{Li}$ content was found in the sample from Hungary $(0.609 \mathrm{mg} / \mathrm{kg})$, but the mushrooms could not be considered as accumulators of $\mathrm{Li}$ [10]. The highest quantity of Se $69 \mu \mathrm{g} / \mathrm{g}$ d.w. found in $P$. ostreatus. In general, most of the wild-growing mushrooms are poor in Se, containing less than $1.0 \mu \mathrm{g} / \mathrm{g}$ d.w. [12]. On the other hand, it is not uncommon to detect higher amounts of $\mathrm{Se}$ in mushrooms, especially in $P$. ostreatus. The concentrations of Se can reach up to $858.0 \mathrm{mg} / \mathrm{kg} \mathrm{d}$.w. when $P$. ostreatus grows on the soil enriched with selenium [13]. That is why, we can conclude that $P$. ostreatus is a very good Se accumulator. The great amount of $\mathrm{Zn}$ and $\mathrm{Cu}$ was also detected in $P$. ostreatus (110.0 and $147.0 \mu \mathrm{g} / \mathrm{g}$ d.w.) and $M$. procera (94 and $109 \mu \mathrm{g} / \mathrm{g} \mathrm{d}$ d.w.). The fruit bodies of mushrooms accumulate remarkably high concentrations of $\mathrm{Cu}$ and $\mathrm{Zn}$ from the soil. Concentrations of these elements found in samples collected in Lugo province in Spain were as high as those in our sample of $M$. procera ( $\mathrm{Zn}: 92.49 \mathrm{mg} / \mathrm{kg}$ d.w.; $\mathrm{Cu}: 217.85 \mathrm{mg} / \mathrm{kg}$ d.w.), while the content of minerals in $P$. ostreatus was lower ( $\mathrm{Zn}$ : 82.77 $\mathrm{mg} / \mathrm{kg}$ d.w.; Cu: $25.22 \mathrm{mg} / \mathrm{kg}$ d.w.). Still, it has been confirmed that mushrooms growing on wood generally contain lower concentrations of heavy metals than fungi growing on soil [14].

Considerable amount of $\mathrm{Pb}$ was found in $M$. procera $(2.0 \mu \mathrm{g} / \mathrm{g}$ d.w.). According to European Commission (2008) maximum level of $\mathrm{Pb}$ in mushrooms is $0.1 \mathrm{mg} / \mathrm{kg}$ calculated on wet weight (w.w.), with the exception of $L$. edodes and $P$. ostreatus $(0.3 \mathrm{mg} / \mathrm{kg}$ w.w) [15]. Considering the fact that fresh mushroom contains approximately $90 \%$ of moisture [16], maximum level of $\mathrm{Pb}$ in dried mushrooms, including $M$. procera, would then be $1.0 \mathrm{mg} / \mathrm{kg} \mathrm{d.w}$. which is still less than the concentration in our sample. Nevertheless, this higher level of $\mathrm{Pb}(1.4-3.5 \mu \mathrm{g} / \mathrm{g})$ was found in caps of $M$. procera in different regions in Poland [17]. Cd was detected only in $L$. edodes in the concentration of $2.0 \mu \mathrm{g} / \mathrm{g} \mathrm{d}$.w., which is the maximum level for $\mathrm{Cd}$ allowed in European Union $(0.2 \mathrm{mg} / \mathrm{kg}$ calculated on fresh weight (f.w.), equivalent to $2.0 \mathrm{mg} / \mathrm{kg}$ d.w., assuming 90\% moisture) [15]. Cadmium accumulation in mushrooms was demonstrated before. Mattila et al. (2001) detected $1.2 \mu \mathrm{g} / \mathrm{g}$ d.w. of $\mathrm{Pb}$ in their sample of $L$. edodes collected in Finland [18], while the highest level of $\mathrm{Pb}$ in the same mushroom collected from Henan province, PRC, was $1.9 \mathrm{mg} / \mathrm{kg} \mathrm{d.w.} \mathrm{[19].} \mathrm{Verily,} \mathrm{Jain} \mathrm{et} \mathrm{al.}$ (2013) found the highest amount of $\mathrm{Pb}$ in dried fruit body of $L$. edodes (mean $4.52 \mathrm{mg} / \mathrm{kg}$ in 2009; mean $4.39 \mathrm{mg} / \mathrm{kg}$ in 2010) [20]. In the same paper, the authors concluded that the concentration of $\mathrm{Pb}$ in mushrooms depends on the cotamination of the soli mushroom grew on, but there is also an opinion that cadmium could be a growth stimulation factor for mushrooms and that high concentration of this element was not the result of environmental contamination with $\mathrm{Cd}$ from the soil [21]. All mushroom samples had considerable amounts of arsenic. The European Commission does not specify the maximum level of As in mushrooms. However, the JEFCA (1988) Provisional Tolerable Daily Intake (PTDI) for inorganic arsenic is 0.002 $\mathrm{mg} / \mathrm{kg}$ b.w., equivalent to $0.12 \mathrm{mg} /$ day for a $60 \mathrm{~kg}$ adult [22]. Also, in Republic of Serbia, the maximum level of As in fresh and processed mushrooms is $0.3 \mathrm{mg} / \mathrm{kg}$ [23]. The normal levels of arsenic in wild mushrooms are usually less than $1 \mathrm{mg} / \mathrm{kg}$ d.w. [24]. However, it is not the first time that mushrooms accumulate As in such a high concentrations in wild mushrooms. It has been reported that values of As vary between 23 and $77 \mu \mathrm{g} / \mathrm{g}$ d.w. and even up to $1420 \mathrm{mg} / \mathrm{kg} \mathrm{d.w}$. in polluted areas of Denmark for Laccaria amethystine [25].

In contrast to vascular plants, macrofungi can accumulate extremely high concentrations of macro- and microelements in their fruiting bodies, even when growing above soils with low metal contents. Elements typically accumulated in include $\mathrm{Au}, \mathrm{Ag}, \mathrm{As}, \mathrm{Br}, \mathrm{Cd}, \mathrm{Cl}, \mathrm{Cs}, \mathrm{Cu}, \mathrm{Hg}, \mathrm{Rb}, \mathrm{Se}, \mathrm{V}$, and $\mathrm{Zn}$, while elements with typically low concentrations in macroungi include $\mathrm{Co}, \mathrm{Cr}, \mathrm{F}, \mathrm{I}, \mathrm{Ni}, \mathrm{Sb}, \mathrm{Sn}, \mathrm{Th}, \mathrm{U}$, and rare earth elements. The bioaccumulation of trace elements in macrofungi depends on various factors, such as bedrock geochemistry, environmental pollution, fungal lifestyle (distribution of mycelia in soil profiles) [9].

\section{CONCLUSIONS}

Tested mushrooms have very good nutritional composition, low energy value and favorable sodium/potassium ratio, but unfortunately they have higher content of heavy metals $(\mathrm{Pb}, \mathrm{As}, \mathrm{Cd})$ than permitted. Since we tested commercial samples, these data are significant, because they indicate that mushrooms were collected in the polluted area. Knowing the importance of the polysaccharide polymers for human health, the tested mushrooms can be a significant source of these compounds. 


\section{Acknowledgment}

The authors are grateful to the Ministry of Education, Science and Technological Development of Serbia for financial support (Grant Nos Ol173021 and TR34012).

\section{Author disclosure statement}

The authors confirm that this article content has no conflict of interest.

\section{REFERENCES}

[1] N.Dalonso, G.H.Goldman, R.M.M.Gern (2015) $\beta$ $(1 \rightarrow 3),(1 \rightarrow 6)$-Glucans: medicinal activities characterization, biosynthesis and new horizons, Applied Microbiology and Biotechnology, 99(19), 7893-7906.

[2] P.Kalač (2013) A review of chemical composition and nutritional value of wild-growing and cultivated mushrooms, Journal of the Science of Food and Agriculture, 93(2), 209-218.

[3] X.M.Wang, J.Zhang, L.H.Wu, Y.L.Zhao, T.Li, J.Q.Li, Y.Z.Wang, H.G.Liu (2014) A mini-review of chemical composition and nutritional value of edible wild-grown mushroom from China, Food Chemistry, 151, 279-285

[4] Association of Official Analytical Chemists (AOAC) (1990) Official methods of analysis, In: Helrich K. ed. Published by the Association of Official Analytical Chemists Inc. Wilson Boulevard Arlington, Virginia 22201 USA, Fifteenth Edition.

[5] D.Higashi, K.Seki, Y.Ishibashi, Y.Egawa, M.Koga, T.Sasaki, K.Hirano, K.Mikami, K.Futami, T.Maekawa, M.Sudo (2012) The effect of lentinan combination therapy for unresectable advanced gastric cancer, Anticancer research, 32(6), 23652368.

[6] M.Jesenak, J.Majtan, Z.Rennerova, J.Kyselovic, P.Banovcin, M.Hrubisko (2013) Immunomodulatory effect of pleuran ( $\beta$-glucan from Pleurotus ostreatus) in children with recurrent respiratory tract infections, International Immunopharmacology, 15(2), 395399.

[7] M.Sari, A.Prange, J.I.Lelley, R.Hambitzer (2017) Screening of beta-glucan contents in commercially cultivated and wild growing mushrooms, Food Chemistry, 216, 45-51.

[8] I.Roncero-Ramos, M.Mendiola-Lanao, M.PérezClavijo, C.Delgado-Andrade (2017) Effect of different cooking methods on nutritional value and antioxidant activity of cultivated mushrooms, International Journal of Food Sciences and Nutrition, 68(3), 287-297.

[9] J.Falandysz, J.Borovička (2013) Macro and trace mineral constituents and radionuclides in mushrooms: health benefits and risks, Applied Microbiology and Biotechnology, 97(2), 477-501.

[10] J.Vetter (2005) Lithium content of some common edible wild-growing mushrooms, Food Chemistry, 90(1-2), 31-37.
[11] F.Costa-Silva,

G.Marques,

C.C.Matos, A.I.R.N.A.Barros, F.M.Nunes (2011) Selenium contents of Portuguese commercial and wild edible mushrooms, Food Chemistry, 126(1), 91-96.

[12] J.Falandysz (2008) Selenium in Edible Mushrooms, Journal of Environmental Science and Health, 26(3), 256-299.

[13] M.C.S.daSilva, J.Naozuka, J.M.R.daLuz, L.S. deAssunção, P.V.Oliveira, M.C.D.Vanetti, D.M.S. Bazzolli, M.C.M.Kasuya (2012) Enrichment of Pleurotus ostreatus mushrooms with selenium in coffee husks, Food Chemistry, 131(2), 558-563.

[14] J.Alonso, M.A.Garcia, M.Perez-Lopez, M.J.Melgar (2003) The Concentrations and Bioconcentration Factors of Copper and Zinc in Edible Mushrooms, Archives of Environmental Contamination and Toxicology, 44(2), 180-188.

[15] EU (2008) Commision Regulation (EC) No $629 / 2008$ of 2 July 2008 amending Regulation (EC) No 1881/2006 setting maximum levels for certain contaminants in foodstuffs, Office J. European Union, L 173/6-9.

[16] M.Gucia, G.Jarzyńska, E.Rafał, M.Roszak, A.K.Kojta, I.Osiej, J.Falandysz (2012) Multivariate analysis of mineral constituents of edible Parasol Mushroom (Macrolepiota procera) and soils beneath fruiting bodies collected from Northern Poland, Environmental science and pollution research international, 19(2), 416-431.

[17] M.Gucia, G.Jarzyńska, A.K.Kojta, J.Falandysz (2012) Temporal variability in 20 chemical elements content of Parasol Mushroom (Macrolepiota procera) collected from two sites over a few years Journal of Environmental Science and Health, 47(2), 81-88.

[18] P.Mattila, K.Könkö, M.Eurola, J.M.Pihlava, J.Astola L.Vahteristo, V.Hietaniemi, J.Kumpulainen, M. Valtonen, V.Piironen (2001) Contents of vitamins, mineral elements, and some phenolic compounds in cultivated mushrooms, Journal of Agricultural and Food Chemistry, 49(5), 2343-2348.

[19] L.S.Fang, Y.H.Yan, S.J. Pei, S.Bing, M.Ying, Z.Ling L.J.Hong (2017) Detection and risk assessment of heavy metal of cadmium in Lentinula edodes from Henan province, Journal of Food Safety and Quality, 8(1), 324-330.

[20] M.Jain, V.K.Gupta, A.Kumar (2013) Bioaccumulation of Cadmium Content in Mushroom and Soil in Delhi-NCR Region of India, Chemical Science Transactions, 2(4).

[21] G.Tyler (1980) Metals in sporophores of Basidiomycetes, Transactions of the British Mycological Society, 74(1), 41-49.

[22] JEFCA (1988) 658. Arsenic, WHO Food Additive, Series 24

[23] Rules book on the maximum allowed quantities of plant protection products residues in food and feed for which the maximum permitted quantities of plant protection products residues were established," SI. glasnik RS, 29/2014. 
[24] P.Kalač (2009) Chemical composition and nutritional value of European species of wild growing mushrooms: A review, Food Chemistry, 113(1)1, 9-16.

[25] E.H.Larsen, M.Hansen, W.Gössler (1998) Speciation and health risk considerations of arsenic in the edible mushroom laccaria amethystina collected from contaminated and uncontaminated locations, Applied Organometallic Chemistry, 12(4), 285-291.

\section{IZVOD}

\section{SASTAV MIKRO I MAKROELEMENATA I NUTRITIVNA VREDNOST U TRI JESTIVE PEČURKE IZ SRBIJE}

Nutritivna vrednost, kao i sadržaj makro- i mikroelemenata testirana je u uzorcima tri jestive pečurke, sakupljene u Srbiji (Pleurotus ostreatus, Lentinula edodes, Macrolepiota procera). Pokazano je da su sve tri gljive bile siromašne energijom, mastima i ugljenimhidratima, ali bogate $\beta$-glukanima. Najzastupljeniji elementi u sva tri uzorka bili su esencijalni makroelementi Ca, K i P, ali je takođe je detektovana značajna količina Li, Se i Zn. Sa druge strane, koncentracija toksičnih metala, Pb, As i Cd, bila je iznad dozvoljenih granica.

Ključne reči: Pleurotus ostreatus, Lentinula edodes, Macrolepiota procera, nutritivna vrednost, analiza hemijskih elemenata.

Naučni rad

Rad primljen: 30. 08. 2017.

Rad prihvaćen: 18. 10. 2017.

Rad je dostupan na sajtu: www.idk.org.rs/casopis

(c) 2018 Authors. Published by Engineering Society for Corrosion. This article is an open access article distributed under the terms and conditions of the Creative Commons Attribution 4.0 International license (https://creativecommons.org/licenses/by/4.0/) 